九州大学学術情報リポジトリ

Kyushu University Institutional Repository

\title{
The Efficient Strategy of Plasmid Rescue from Tn5 Mutants Derived from Bradyrhizobium japonicum Is-1, Based on Whole Genome Sequence Information of Strain USDA110
}

Tsurumaru, Hirohito

九州大学大学院生物資源環境科学府 ·独立行政法人製品評価技術基盤機構

Yamakawa, Takeo

Department of Plant Resources Faculty of Agriculture Kyushu University

Tanaka, Masayuki

Graduate school of Bioresource and Bioenvironmental Sciences, kyushu university - Department of Production \& Development, Asahi Food \& Healthcare Ltd.,

Sakai, Masao

Department of Plant Resources Faculty of Agriculture Kyushu University

https://doi.org/10.5109/10065

出版情報：九州大学大学院農学研究院紀要. 53 (1)，pp.27-31，2008-02-28. Faculty of Agriculture， Kyushu University

バージョン :

権利関係 : 


\title{
The Efficient Strategy of Plasmid Rescue from Tn5 Mutants Derived from Bradyrhizobium japonicum Is-1, Based on Whole Genome Sequence Information of Strain USDA110
}

\author{
Hirohito TSURUMARU ${ }^{1,2}$, Takeo YAMAKAWA*, Masayuki TANAKA ${ }^{1,3}$ \\ and Masao SAKAI
}

\author{
Laboratory of Plant Nutrition, Division of Soil Science and Plant Production, Department of Plant Resources, \\ Faculty of Agriculture, Kyushu University, Fukuoka 812-8581, Japan \\ (Received November 8, 2007 and accepted November 30, 2007)
}

\begin{abstract}
We previously reported that Tn5 mutants derived from Bradyrhizobium japonicum Is-1 were isolated. In this report, Tn5-encoded kanamycin resistance cassette and its flanking sequence were concurrently cloned into cosmid vector from Tn5 mutants. In general, the genomic southern blot analysis is often performed to select appropriate restriction enzyme before performing the plasmid rescue from cosmid clone. Therefore plasmid rescue experiment consumes the time, especially when more than one Tn5 mutant was obtained. To improve this situation, tentative restriction map of strain Is-1 was constructed based on whole genome sequence information of strain USDA110. Plasmid rescue was performed with restriction enzymes selected according to this map and these enzymes were appropriate for plasmid rescue. This strategy is thought to be effective for saving the time of plasmid rescue in B. japonicum strains other than USDA110.
\end{abstract}

\section{INTRODUCTION}

Transposon mutagenesis is a powerful strategy to identify the novel gene. In rhizobia, Tn5 mutagenesis has been used for the identifications of nod, fix and nif genes (Deshmane and Stacey 1989; Rossen et al., 1984; Corbin et al., 1982). Once Tn5 mutant is isolated, it is necessary to determine the Tn5-falanking sequence to deduce the gene product disrupted by Tn5 insertion. When both a kanamycine resistant gene and its flanking sequence were cloned from Tn5 mutant, "rescue" method (Guilhabert et al., 2001) is often used. The rescue method consists of a four-step procedure: 1) the genomic cosmid library of Tn5 mutant is constructed; 2) a cosmid clone containing the Tn5 is selected with Kanamycin-containing medium; 3) a cosmid is digested with appropriate restriction enzyme and digestedDNA fragment containing the Tn5 is cloned into plasmid vector; 4) constructed plasmid is sequenced to determine the Tn5-flanking sequence. The plasmid rescue experiment consumes time, especially when more than one mutant was obtained. Actually we obtained more than one Tn5 mutant of Bradyrhizobium japonicum Is-1 with altered compatibility with $R j_{2}$-soybean cultivars (Tsurumaru et al., 2008). Though the change of host range was common to these Tn5 mutants, Tn5 insertion sites were different from each other and all homologous sequences to

Laboratory of Plant Nutrition, Graduate School of Bioresource and Bioenvironmental Sciences, Kyushu University

Biological Resource Center, National Institute of Technology and Evaluation (NITE), 2-5-8 Kazusakamatari, Kisarazu-shi, Chiba 292-0818, Japan

${ }^{3}$ Department of Production \& Development, Asahi Food \& Healthcare Ltd., 1-23-1 Azumabashi, Sumida-ku, Tokyo 1308602, Japan

* Corresponding author (E-mail: yamakawa@agr.kyushu-u. ac.jp)
Tn5-flanking sequence were found in the complete genome sequence of $B$. japonicum USDA 110. In cases like this, PCR-based method to identify the gene disrupted by Tn5 is efficient (Kwon and Ricke, 2000). However PCR-based method has sometimes disadvantage such as that there is amplification error (Cline et al., 1996). Because the complete genome sequences of B. japonicum strains other than USDA110 are not determined, it is not able to confirm the accuracy of sequence of PCR products in these strains. In Tn5 mutants of strain Is-1, it is preferable to use conventional approach such as plasmid rescue, which is not based on PCR method, for determining the complete sequence of the gene disrupted by $\mathrm{Tn} 5$.

In this report, we constructed the tentative restriction map that contains Tn5 insertion site of strain Is-1, based on whole genome sequence of $B$. japonicum strain USDA110 (Kaneko et al., 2002). According to this map, the appropriate restriction enzyme was selected for digesting the cosmid containing the Tn5 and recloning this DNA fragment into plasmid vector. This strategy saves the time in the third-step procedure (described above) of the rescue method.

\section{MATERIALS AND METHOD}

\section{Bacterial strains and plasmids}

Bacterial strains, cosmids and plasmids used in this study were described in Table 1 . Tn5 mutants of $B$. japonicum strain Is-1 were grown on HM salt medium (Cole and Elkan, 1973) supplemented with 0.1\% arabinose at $30^{\circ} \mathrm{C}$. E. coli strains were grown on LuriaBertani medium (Sambrook et al., 1989) at $37^{\circ} \mathrm{C}$. Antibiotics were added to the media at the following final concentrations: kanamycin at $50 \mu \mathrm{g} \mathrm{mL}^{-1}$ for Tn5 mutant and ampicillin at $100 \mu \mathrm{g} \mathrm{mL}^{-1}$ and kanamycin at $50 \mu \mathrm{g} \mathrm{mL} \mathrm{L}^{-1}$ for E. coli harboring Tn5-containing cosmid or plasmid clone (Table 1). 
Table 1. Bacterial strains, cosmids and plasmids used in this study

\begin{tabular}{|c|c|c|}
\hline Strain and plasmid & Relevant characteristics ${ }^{* 1}$ & Reference or source \\
\hline \multicolumn{3}{|l|}{ B. japonicum } \\
\hline Is -1 & incompatible with $R j_{2} R j_{3}$ soybean and compatible $R j_{4}$ one & Ishizuka et al. (1991) \\
\hline $1 \mathrm{C} 1$ & Is- $1:: \operatorname{Tn} 5, \mathrm{Km}^{\mathrm{r}}$ & Tsurumaru et al. (2008) \\
\hline $1 \mathrm{C} 2$ & Is- $1:: \operatorname{Tn} 5, \mathrm{Km}^{\mathrm{r}}$ & Tsurumaru et al. (2008) \\
\hline $5 \mathrm{C} 1$ & Is- $-1: \operatorname{Tn} 5, \mathrm{Km}^{\mathrm{r}}$ & Tsurumaru et al. (2008) \\
\hline $6 \mathrm{C} 1$ & Is $-1:: \operatorname{Tn} 5, \mathrm{Km}^{\mathrm{r}}$ & Tsurumaru et al. (2008) \\
\hline $7 \mathrm{C} 1$ & Is $-1:: \operatorname{Tn} 5, \mathrm{Km}^{\mathrm{r}}$ & Tsurumaru et al. (2008) \\
\hline $7 \mathrm{C} 2$ & Is $-1:: \operatorname{Tn} 5, \mathrm{Km}^{\mathrm{r}}$ & Tsurumaru et al. (2008) \\
\hline $10 \mathrm{C} 1$ & Tn5-induced spontaneous mutant, $\mathrm{Km}^{\mathrm{r}}$ & Tsurumaru et al. (2008) \\
\hline $10 \mathrm{C} 2$ & Is $-1:: \operatorname{Tn} 5, \mathrm{Km}^{\mathrm{r}}$ & Tsurumaru et al. (2008) \\
\hline \multicolumn{3}{|l|}{ E. coli } \\
\hline JM109 & recA1 ; cloning strain & Takara Bio Inc., Shiga, Japan \\
\hline \multicolumn{3}{|l|}{ Cosmid } \\
\hline SuperCos I & constructing SuperCos I-Neo, Ap ${ }^{\mathrm{r}}, \mathrm{Km}^{\mathrm{r}}$ & Stratagene, CA, USA \\
\hline SuperCos I-Neo & cloning of partially digested genomic DNAs, $\mathrm{Ap}^{\mathrm{r}}$ & This study \\
\hline pSUP1C1 & genomic DNA of $1 \mathrm{C} 1$ is cloned, $\mathrm{Ap}^{\mathrm{r}}, \mathrm{Km}^{\mathrm{r}}$ & This study \\
\hline pSUP1C2 & genomic DNA of $1 \mathrm{C} 2$ is cloned, $\mathrm{Ap}^{\mathrm{r}}, \mathrm{Km}^{\mathrm{r}}$ & This study \\
\hline pSUP5C1 & genomic DNA of $5 \mathrm{C} 1$ is cloned, $\mathrm{Ap}^{\mathrm{r}}, \mathrm{Km}^{\mathrm{r}}$ & This study \\
\hline pSUP6C1 & genomic DNA of $6 \mathrm{C} 1$ is cloned, $\mathrm{Ap}^{\mathrm{r}}, \mathrm{Km}^{\mathrm{r}}$ & This study \\
\hline pSUP7C1 & genomic DNA of $7 \mathrm{C} 1$ is cloned, $\mathrm{Ap}^{\mathrm{r}}, \mathrm{Km}^{\mathrm{r}}$ & This study \\
\hline pSUP7C2 & genomic DNA of 7C2 is cloned, $\mathrm{Ap}^{\mathrm{r}}, \mathrm{Km}^{\mathrm{r}}$ & This study \\
\hline pSUP10C2 & genomic DNA of $10 \mathrm{C} 2$ is cloned, $\mathrm{Ap}^{\mathrm{r}}, \mathrm{Km}^{\mathrm{r}}$ & This study \\
\hline \multicolumn{3}{|l|}{ Plasmid } \\
\hline pGEM-3Zf(-) & Subcloning vector, $\mathrm{Ap}^{\mathrm{r}}$ & Promega, MA, USA \\
\hline pGEM-5Zf $(+)$ & Subcloning vector, $\mathrm{Ap}^{\mathrm{r}}$ & Promega, MA, USA \\
\hline pGApa1C1 & 6.0-kbp Apa I fragment of pSUP1C1-1 is subcloned, $\mathrm{Ap}^{\mathrm{r}}, \mathrm{Km}^{\mathrm{r}}$ & This study \\
\hline pGH1C2 & 4.5-kbp Hinc II fragment of pSUP1C2-5 is subcloned, $\mathrm{Ap}^{\mathrm{r}}, \mathrm{Km}^{\mathrm{r}}$ & This study \\
\hline pGAcc5C1 & 5.0-kbp Acc I fragment of pSUP5C1-1 is subcloned, $\mathrm{Ap}^{\mathrm{r}}, \mathrm{Km}^{\mathrm{r}}$ & This study \\
\hline pGA6C1 & 4.6-kbp Aat II fragment of pSUP6C1-3 is subcloned, $\mathrm{Ap}^{\mathrm{r}}, \mathrm{Km}^{\mathrm{r}}$ & This study \\
\hline pGSphIII7C1-1 & 4.4-kbp Sph I fragment of pSUP7C1-9 is subcloned, $\mathrm{Ap}^{\mathrm{r}}, \mathrm{Km}^{\mathrm{r}}$ & This study \\
\hline pGA7C2 & 5.5-kbp Aat II fragment of pSUP7C2-4 is subcloned, $\mathrm{Ap}^{\mathrm{r}}, \mathrm{Km}^{\mathrm{r}}$ & This study \\
\hline pGApa10C2 & 9.3-kbp Apa I fragment of pSUP10C2-1 is subcloned, $\mathrm{Ap}^{\mathrm{r}}, \mathrm{Km}^{\mathrm{r}}$ & This study \\
\hline
\end{tabular}

${ }^{* 1} \mathrm{Km}^{\mathrm{r}}$ : kanamycin resistance, $\mathrm{Ap}^{\mathrm{r}}$ : ampicillin resistance.

\section{Tn5-flanking sequence}

Kwon and Ricke (2000) developed efficient method to amplify specifically the transposon-flanking sequences with unique Y-shape linkers. We previously isolated Tn5 mutants derived from strain Is-1 and showed Tn5-flanking sequences according to their method (Tsurumaru et al., 2008). All homologous sequences to them were found in the genome of $B$. japonicum USDA110. The open reading frames (ORFs) containing homologous sequence inside or upstream of itself and the sequence positions of these ORFs are shown in Table 2. The complete genome sequence information of B. japonicum USDA110 was obtained from RhizoBase (http://bacteria.kazusa.or.jp/ rhizobase/Bradyrhizobium/index.html). This information was used for constructing tentative restriction map of strain Is-1.

Table 2. Open reading frame (ORF), containing homologous sequence to Tn5-flanking sequence of Tn 5 mutants derived from strain Is-1, in RhizoBase

\begin{tabular}{cccr}
\hline Tn5 mutant & ORF*1 & Location*2 & Length \\
\hline 1C1 & bll4521 & $5009041-5010171 \mathrm{~b}$ & $1130 \mathrm{bp}$ \\
$1 \mathrm{C} 2^{* 3}$ & bsr7468 & $8203674-8203889 \mathrm{~b}$ & $215 \mathrm{bp}$ \\
$5 \mathrm{C} 1$ & blr1414 & $1540332-1540634 \mathrm{~b}$ & $302 \mathrm{bp}$ \\
$6 \mathrm{C} 1$ & bll1193 & $1307182-1309080 \mathrm{~b}$ & $1898 \mathrm{bp}$ \\
$7 \mathrm{C} 1$ & bll5593 & $6149267-6150277 \mathrm{~b}$ & $1010 \mathrm{bp}$ \\
$7 \mathrm{C} 2$ & blr5786 & $6353093-6353491 \mathrm{~b}$ & $398 \mathrm{bp}$ \\
$10 \mathrm{C} 2$ & bll5123 & $5682342-5683715 \mathrm{~b}$ & $1373 \mathrm{bp}$ \\
\hline
\end{tabular}

*1 ORF of USDA110 which contains the homologous sequence to Tn5-flanking sequence inside or upstream of itself is showed.

*2 Location of ORF in the genome of USDA110 is showed.

*3 Homologous sequence to Tn5-flanking sequence of 1C2 is located in the upstream of $\operatorname{bsr} 7468$. 


\section{Construction of a cosmid vector}

SuperCos I-Neo was constructed as described below. First, SuperCos I cosmid vector (Stratagene, CA, USA) was digested by Bal I (Roche Diagnostics, Basel, Switzerland) and Sma I (Takara Bio Inc., Shiga, Japan) to eliminate the neomycin resistant gene.
Finally the Bal I/Sma I-digested SuperCos I was selfligated using T4 DNA ligase (Stratagene, CA, USA).

\section{Cloning of kanamycin resistance region into cos-} mid vector

Genomic DNA was isolated by the method of

A
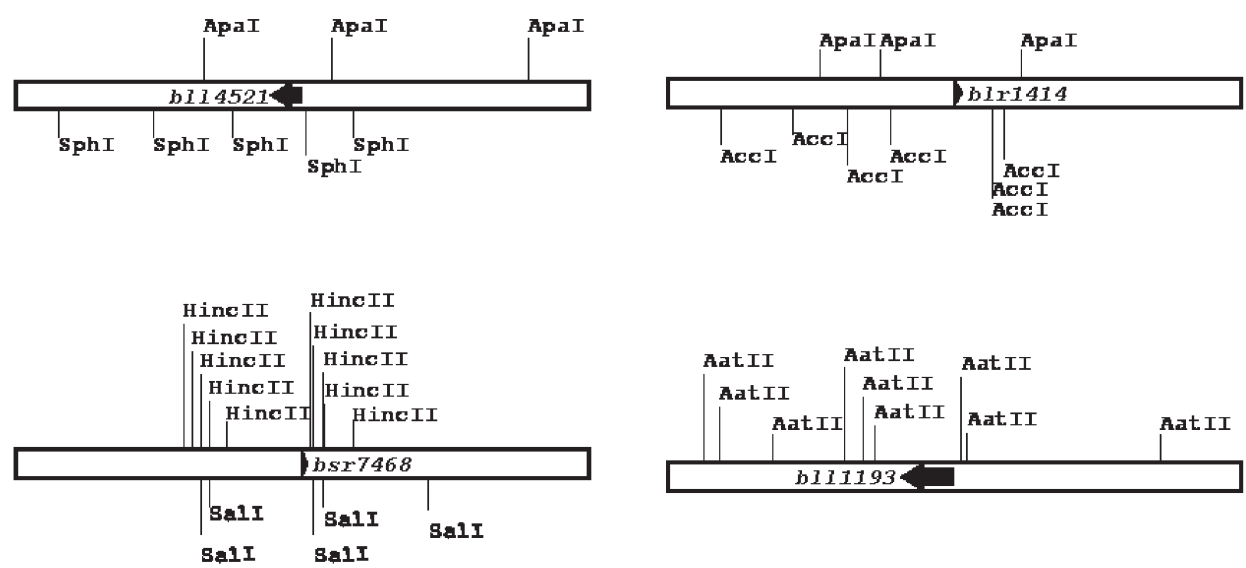

B
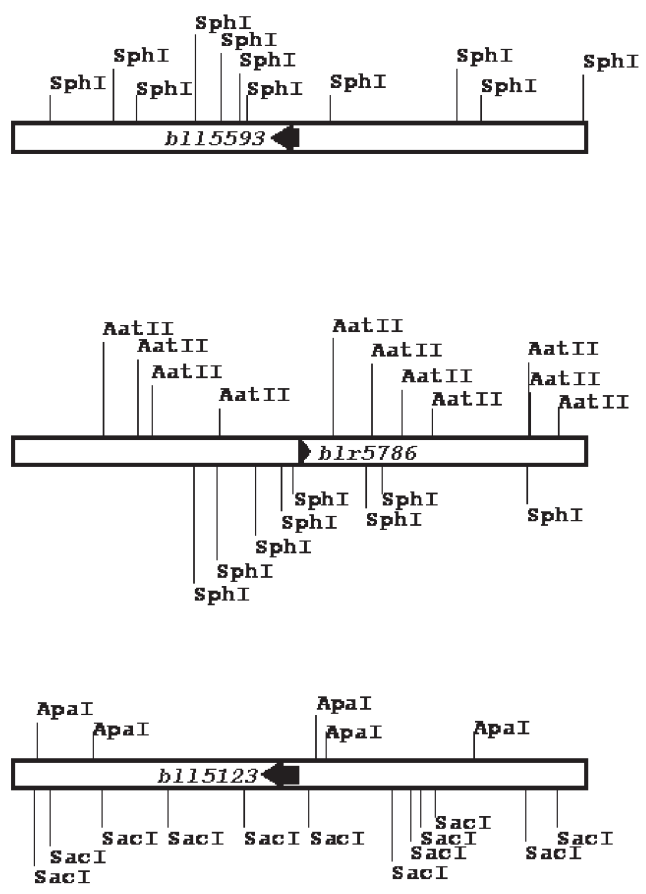

Fig. 1. The restriction maps in the vicinities of the genes, which have high similarities with Tn5-flanking sequences, in B. japonicum strain USDA110.

The bll4521, bsr7468, blr1414 and bll1193 genes are showed in panel A. The bll5593, blr5786 and bll5123 genes are showed in panel B. These genes have high similarities with Tn5-flanking sequences of $1 \mathrm{C} 1,1 \mathrm{C} 2,5 \mathrm{C} 1,6 \mathrm{C} 1,7 \mathrm{C} 1,7 \mathrm{C} 2$ and 10C2, respectively. The sequences in the vicinities of these genes were obtained from the RhizoBase. The restriction maps were constructed by Genetyx software (Genetyx, Tokyo, Japan) with these sequences. Because we assumed that the vicinities of Tn5-inserted genes in Tn5 mutants of B. japonicum strain Is-1 have also high similarities with ones of above-described genes in B. japonicum strain USDA110, these maps were served as the tentative restriction maps in Tn5 mutants for plasmid rescue. In this study, we confirmed that the strategy based on this assumption was viable (as described in results). 
Pitcher et al. (1989). The kanamycin resistance cassette and its flanking sequence (Kanamycin resistance region) were cloned into SuperCos I-Neo following instructions of SuperCos I cosmid vector kit and Gigapack III Gold-4 packaging Extract (Stratagene, CA, USA).

\section{Construction of the tentative restriction map based on the RhizoBase and plasmid rescue according to this map}

A 2000-bp sequence containing ORF which has high similarity to the Tn5-flanking sequence was obtained from the RhizoBase. This sequence extends from $1000 \mathrm{bp}$ upstream of to $1000 \mathrm{bp}$ downstream of the translation start site of this ORF. Restriction map of this sequence was constructed with Genetyx software (Genetyx, Tokyo, Japan). These maps were used as the tentative restriction map for plasmid rescue experiment (Fig. 1). According to these tentative restriction maps, restriction enzymes were selected. These restriction enzymes do not cut both Tn5 (accession number of DNA data bank of Japan, AB158755) and the ORF that have high similarity to the Tn5-flanking sequence (Tsurumaru et al., 2008). The pGEM-3Zf(-) or pGEM-5Zf(+) were used as cloning vector.

\section{RESULTS}

\section{The rescue of the kanamycin resistance region}

Partially digested genomic DNAs from all Tn5 mutants were ligated into the SuperCos I-Neo cosmid vector. The cosmid clones containing transposon-encoded kanamycin resistance gene were obtained from all mutants except for mutant 10C1 (Table 1). No cosmid clone showing the kanamycin resistance was obtained from 10C1. According to the tentative restriction map (Fig. 1), Apa I, Hinc II, Acc I, Aat II, Sph I, Aat II and Apa I were used for plasmid rescue from cosmid clones of $1 \mathrm{C} 1,1 \mathrm{C} 2,5 \mathrm{C} 1,6 \mathrm{C} 1,7 \mathrm{C} 1,7 \mathrm{C} 2$ and $10 \mathrm{C} 2$ respectively. Constructed plasmids were showed in Table 1 and sequenced commercially by Macrogen Inc. (Seoul, Korea).

\section{Deposition of the sequences determined in this study}

All restriction enzymes selected according to the tentative restriction map were worked for plasmid rescue. The sequences of these plasmids determined in this study were deposited to DNA Data Bank of Japan (DDBJ) database (sequential accession numbers AB243409 through AB243415). Sequence analysis showed that these plasmids contained Tn5-flanking sequences that were determined by using the method of Kwon and Ricke (2000). A 773 bp sequence extending from $1,110 \mathrm{~b}$ to $1,882 \mathrm{~b}$ in $1 \mathrm{C} 1$ (accession number AB243409), $756 \mathrm{bp}$ sequence extending from 905 to 1,660 b in 5C1 (AB243411), 227 bp sequence extending from 1,625 to $1,851 \mathrm{~b}$ in $6 \mathrm{C} 1$ (AB243412), 1,896 bp sequence extending from 1,050 to $2,945 \mathrm{~b}$ in $7 \mathrm{C} 1$ (AB243413) and $234 \mathrm{bp}$ sequence extending from 1,174 to 1,407 b in 10C2 (AB243415) correspond to the Tn5flanking sequences, respectively. A 369 bp sequence extending from 2,573 to 2,941 b in 1C2 (AB243410) and $932 \mathrm{bp}$ sequence extending from 501 to $1,432 \mathrm{~b}$ in $7 \mathrm{C} 2$ (AB243414) correspond to a part of the Tn5-flanking sequences.

\section{DISCUSSION}

The tentative restriction map of strain Is-1 was constructed with both information of Tn5-flanking sequence and RhizoBase. The restriction enzymes used for plasmid rescue were selected according to these maps. Because this strategy worked in case of strain Is-1, it may be viable in B. japonicum strains other than Is-1. However this strategy may have disadvantage because it does not work when a Tn5-flanking sequence from mutant has no similarity with any sequence in the RhizoBase. In addition, we can not tell whether a Tn5-flanking sequence in mutant derived from $B$. elkanii has high similarity with the sequence of some gene in RhizoBase, because B. japonicum is clearly a separate species from $B$. elkanii on the basis of $16 \mathrm{~S}$ rDNA similarities and total DNA homology values (Willems et al., 2001).

Once the Tn5-disrupted gene is identified, it is necessary to confirm whether its gene is responsible for the phenotype change in Tn5 mutant. Therefore the complementation experiment is usually performed after identification of Tn5-disrupted gene. A complementation experiment consists of a four-step procedure: 1) the genomic cosmid library of wild type strain is constructed; 2) a cosmid clone containing the Tn5 insertion site is selected from it's library by colony hybridization with a DNA probe based on Tn5-flanking sequence in Tn5 mutant; 3) a cosmid is digested with appropriate restriction enzyme and digested-DNA fragment is cloned into plasmid vector; 4) constructed plasmid is transformed into Tn5 mutant to confirm whether the complemented mutant shows the wild type phenotype. In second-step in complement experiment, there are sometimes negative clones in candidate clones selected by colony hybridization. The strategy with tentative restriction map may be applied for selection of true positive clones from Is-1 genomic library. Basically, it is only necessary to confirm that there is Tn5-flanking sequence in tentative map based on end sequence of candidate clones. The rapid selection protocol of positive clones will be described in more detail in the next paper to confirm that Tn5 insertion is responsible for the acquisition of ability to nodulate $R j_{2}$ soybean.

\section{REFERENCES}

Cline, J., J. C. Braman and H. H. Hogrefe 1996 PCR fidelity of Pfu DNA polymerase and other thermostable DNA polymerases. Nucleic Acids Res., 24: 3546-3551

Cole, M. A. and G. H. Elkan 1973 Transmissible resistance to penicillin G, neomycin, and chloramphenicol in Rhizobium japonicum. Antimicrob. Agents Chemother., 4: 248-253

Corbin, D., G. Ditta and D. R. Helinski 1982 Clustering of nitro- 
gen fixation ( $n$ if) genes in Rhizobium meliloti. J. Bacteriol., 149: 221-228

Deshmane, N. and G. Stacey 1989 Identification of Bradyrhizobium nod genes involved in host-specific nodulation. J. Bacteriol., 171: 3324-3330

Guilhabert, M. R., L. M. Hoffman, D. A. Mills and B. C. Kirkpatrick 2001 Transposon mutagenesis of Xylella fastidiosa by electroporation of Tn5 synaptic complexes. Mol. Plant Microbe. Interact., 14: 701-706

Ishizuka, J., A. Yokoyama and Y. Suemasu 1991 Relationship between serotypes of Bradyrhizobium japonicum and their compatibility with $R j$-cultivars for nodulation. Soil Sci. Plant Nutr., 37: 23-30

Kaneko, T., Y. Nakamura, S. Sato, K. Minamisawa, T. Uchiumi, S. Sasamoto, A. Watanabe, K. Idesawa, M. Iriguchi, K. Kawashima, M. Kohara, M. Matsumoto, S S.himpo, H. Tsuruoka, T. Wada, M. Yamada and S. Tabata 2002 Complete genomic sequence of nitrogen-fixing symbiotic bacterium Bradyrhizobium japonicum USDA110. DNA Res., 9: 189-197
Kwon, Y. M. and S. C. Ricke 2000 Efficient amplification of multiple transposon-flanking sequences. J. Microbiol. Methods, 41: $195-199$

Pitcher, D. G., N. A. Saunders and R. J. Owen 1989 Rapid extraction of bacterial genomic DNA with guanidium thiocyanate. Lett. Appl. Microbiol., 8: 151-156

Rosen, B. P., H. Bhattacharjee and W. Shi 1995 Mechanisms of metalloregulation of an anion-translocating ATPase. $J$ Bioenerg. Biomembr., 27: 85-91

Sambrook, J., E. F. Fritsch and T. Maniatis 1989 Molecular Cloning: A Laboratory Manual, 2nd. Cold Spring Harbor Laboratory Press, Cold Spring Harbor, NY, USA

Tsurumaru, H., T. Yamakawa, M. Tanaka and M. Sakai 2008 Tn5 mutants of Bradyrhizobium japonicum Is-1 with altered compatibility with $R j_{2}$-soybean cultivars. Soil Sci. Plant Nutr., 54: accepted (14-Oct-2007)

Willems, A., R. Coopman and M. Gillis 2001 Phylogenetic and DNA-DNA hybridization analyses of Bradyrhizobium species. Int. J. Syst. Evol. Microbiol., 51: 111-117 
